Schulich School of Law, Dalhousie University

Schulich Law Scholars

2017

Development versus Preservation Interests in the Making of a Music City: A Case Study of Select Iconic Toronto Music Venues and the Treatment of Their Intangible Cultural Heritage Value

Sara Gwendolyn Ross

Follow this and additional works at: https://digitalcommons.schulichlaw.dal.ca/scholarly_works

Part of the Cultural Heritage Law Commons, and the Law and Society Commons 


\title{
Development versus Preservation Interests in the Making of a Music City: A Case Study of Select Iconic Toronto Music Venues and the Treatment of Their Intangible Cultural Heritage Value
}

\author{
Sara Gwendolyn Ross*
}

\begin{abstract}
Urban redevelopment projects increasingly draw on culture as a tool for rejuvenating city spaces but, in doing so, can overemphasize the economic or exchange-value potential of a cultural space to the detriment of what was initially meaningful about a space - that which carries great cultural community wealth, use-value, or embodies a group's intangible cultural heritage. Development and preservation interests illustrate this tension in terms of how cultural heritageboth tangible and intangible-is managed in the city. This article will turn to Toronto's "Music City" strategy that is being deployed as part of a culturefocused urban redevelopment trend and Creative City planning initiative in order to examine how the modern urban intangible merits of city spaces are valuated and dealt with in light of the comparatively weak regard accorded to intangibility within the available heritage protection legal frameworks of Canada, Ontario, and, specifically, Toronto. The currently underdeveloped recognition for intangibility in the heritage protection equation not only fails to equally valuate non-dominant, unconventional, or alternative iterations of culture but also falls behind the key guiding documents in international law for the safeguarding and recognition of intangible cultural heritage as well as in accounting for intangibility in determining heritage value. Without diligent inclusive strategies to account for, and consult, the diverse spectrum of groups, cultures, and cultural spaces affected by urban heritage and cultural city planning
\end{abstract}

^PhD candidate, Osgoode Hall Law School, Toronto, Canada, and Member of the Ontario Bar; Email: sross084@uottawa.ca

ACKNOWLEDGMENTS: The author would like to thank Ruth Buchanan for her advice on earlier versions of this article, in addition to Alexander Bauer, editor of this journal, and the anonymous peer reviewers for their helpful comments on improving this article. 
processes, a city's development initiatives risk counterproductively destroying the precise characteristics they are otherwise seeking to nourish, create, and, even, commodify.

With its few remnants of Victorian and art-deco architecture overpowered by hastily assembled modern towers of concrete and glass, Toronto has developed a not-undeserved reputation for paving over its past and short-changing its future.

— Stuart Berman ${ }^{1}$

\section{INTRODUCTION}

Urban redevelopment projects that draw on culture as a tool for rejuvenation often display a persistent tension between different ways of valuing spaces in the city. Existing spaces may carry great meaning as they are, but development interests may focus on how these spaces could be more economically valuable if transformed to attract and optimize consumer expenditure. As a result, the notion of what is meaningful about a space-or what carries great cultural community wealth, use-value, or embodies a group's intangible cultural heritage_-often takes a back seat in determining the redevelopment processes of cultural spaces in the city. Within these redevelopment and rejuvenation discussions, Sharon Zukin's three loosely defined, but often overlapping, camps can be identified: those who focus on historic preservation concerns, those who focus on community preservation concerns, and those who fall under the increasingly vague catch-all term of "gentrifiers."2

In terms of the heritage values of these camps, opinions often clash over questions of whether the future should be privileged over the past, whether heritage should be privileged over innovation, whether heritage preservation is simply a form of outdated nostalgia, or what constitutes "heritage," along with what kinds of heritage and whose heritage matters, and how to determine which spaces-whose spaces-merit protection and/or preservation. ${ }^{3}$ While the dissonance between these various groups pepper the pages of city news sources, social media, and neighborhood coffee shop chatter, the mechanics of these battles are fought within the intricate legal frameworks of interrelated municipal and provincial zoning as well as planning legislation and decisions, in addition to overarching federal policies and international norms - or what might be lumped together for our present purpose as the relevant legal complexes that shape our cities. ${ }^{4}$ It is here within the "lawscapes," where the law and the city meet, where the diversity of vested interests in the city space must be-it is hoped—equally valuated and addressed. ${ }^{5}$

Without designing inclusive strategies for effectively consulting the diverse spectrum of parties and cultures affected by urban heritage and cultural city planning processes, a city's development initiatives risk counterproductively destroying the precise characteristics they are otherwise seeking to nourish, create, and, even, 
commodify. ${ }^{6}$ And without diligent and critical consideration of how a city's modern urban heritage and spaces of key cultural practice and consumption are dealt with, a city risks, in Zukin's words, losing its soul. ${ }^{7}$

When it is determined that a building has heritage merit-whether it is intangible or tangible - the space may be dealt with in a number of ways. Preservation, conservation, restoration, renovation, restoration, adaptive re-use, or demolition and replacement will all amount to a different treatment of the tangible heritage merits of a space. ${ }^{8}$ But the intangible heritage merits of a space will be directly or indirectly affected as well. This article is concerned with the ways in which the modern urban intangible merits of city spaces are valuated and dealt with in light of the comparatively weak regard accorded to intangibility within the available heritage protection legal frameworks of Canada, Ontario, and, specifically, Toronto.

The currently underdeveloped recognition for intangibility in the heritage protection equation not only fails to equally valuate non-dominant, unconventional, or alternative iterations of culture but also falls behind the key guiding documents in international law for the safeguarding and recognition of intangible cultural heritage and in accounting for intangibility in determinations of heritage value. ${ }^{9}$ In examining such concerns, this article will turn to Toronto's "Music City" strategy that is being deployed as part of a culture-focused urban redevelopment and "Creative City" planning initiative. ${ }^{10}$ A selection of Toronto's iconic music venues affected by redevelopment processes will be considered for the range in treatment of their heritage merits. The various ways in which the past and future of these music spaces are dealt with reveals how the exchange-value potential of transgressive or unconventional venues and spaces in a city tends to be valuated more highly than the usevalue of these spaces of intangible urban cultural heritage, where their use-value and intangible merits frequently go entirely unrecognized and unassessed in redevelopment decision-making processes. This undervaluation may ultimately result in the destruction of the precise attributes a city professes a desire to establish and grow as well as contribute to intergenerational injustice in failing to preserve what may be key elements of Toronto's musical past and present in building a vibrant musical future.

\section{THE “MUSIC CITY”: CULTURE AND THE ARTS AS URBAN REDEVELOPMENT TOOLS}

Like many major cities across the globe that are hoping to attain "world city" status, Toronto (along with many of the communities that surround it along the shores of the Great Lakes) has turned to "culture" and the "arts" as guiding tools and a panacea in its current urban redevelopment projects. ${ }^{11}$ Here, culture is seen both for its ability to contribute to a potentially higher quality of life and leisure in the city as well as for its lucrative economic attributes in drawing tourists and attracting the soughtafter, murkily identifiable "creative class." 12 One of the particular initiatives in these development strategies is Toronto's "Music City" strategy. Primarily stemming from documents and reports where municipal economic and development strategies have 
turned to the music industry as a growth resource — such as "Collaborating for Competitiveness: A Strategic Plan to Accelerate Economic Growth and Job Creation in Toronto" and "Creative Capital Gains: An Action Plan for Toronto"13_-Toronto's Music City plans are a relatively recent development in Toronto's Creative Cityoriented rejuvenation strategy. As a director for one of Toronto's major annual music and arts festivals "North by Northeast" explains, "[w] hat everyone's getting ... is that not only is music essential for the soul and the imagination, spiritual aspiration of a city, it makes cities money. Like, tons of it." 14 Or, as the president of Music Canada, Graham Henderson, explains, "[w]e know that live music is an essential piece of our music story in Ontario and yet, no one has truly tried to capture the extent of its impact on our economy, workforce and communities."15

The guiding document in defining what constitutes a Music City, "The Mastering of a Music City," notes that "[t]he term 'Music City' is becoming widely used in cultural communities and has penetrated the political vernacular in many cities around the world ... [and] describes communities of various sizes that have a vibrant music economy which they actively promote." 16 "The Mastering of a Music City" follows the 2014 launch of Measuring Live Music Canada, a study designed to measure the economic impact of live music in Ontario, ${ }^{17}$ which itself came on the heels of the 2013 report "The Next Big Bang," commissioned by Music Canada to explore new strategies to support and grow Canada's music industry. ${ }^{18}$

Among the key identified marketable musical assets and cultural capital that a city can promote are "noteworthy or iconic music venues" and "a rich musical history" where

[i]conic live music venues can also be compelling tourist attractions and strong branding tools for cities. If marketed with a clear and consistent image, a venue of significant heritage or reputation has the potential to draw music fans based purely on its legacy or buzz. Venues catering to specific genres of music or cultural groups can also appeal to tourists. ${ }^{19}$

The 2013 report goes on to note that the musical landmarks of a city can be leveraged by governments in partnership "with the venue owners to create mutually beneficial promotional campaigns." 20

Additionally, many of the reported observations emphasize the growing importance of live music venues in Canada for a number of reasons. The collapse of the market for music products has led to the increased importance of touring for musicians, requiring suitable venues for live musical performance. ${ }^{21}$ As a result, in addition to smaller or more intimate music venues that provide a space for local musical acts to grow and perform, venues that can house large events and serve as higher price-point music consumption and dancing spaces are also necessary. But even though redevelopment strategies and guiding documents that capitalize on existing forms of music culture and heritage comprise part of the legal complexes that shape Creative City plans for Toronto, key music venues and music culture spaces continue to disappear due to other municipal policy and planning documents that deploy conflicting strategies, all while professing to stay in line with Creative City redevelopment strategies. ${ }^{22}$ 
Whether displaced venues and music spaces have been replaced with parking lots, condominiums, the latest mixed-use redevelopment project, or another kind of commercial space, the current system in place has caused the destruction of important music venues and spaces in Toronto within which the rich fabric of Toronto's live music and music culture is generated. ${ }^{23}$ Drawn from a series of consultations conducted by Heritage Toronto and the Toronto Historical Association, the 2010 "Heritage Voices" report on heritage preservation issues pinpoints provincial planning processes as problematic to preservation goals and identifies a tendency by the Ontario Municipal Board (OMB) to favor developer interests over cultural heritage interests. ${ }^{24}$ The report notes that there are only a few exceptions where cultural heritage preservation has won out over a development proposal in appeals to the OMB concerning land-use planning disputes. ${ }^{25}$ As we will see below, the Toronto music venue, the Silver Dollar Room, represents one of these exceptions.

\section{CASE STUDIES}

\section{The Silver Dollar Room}

Located near the intersection of Spadina and College in downtown Toronto's Harbord Village, next to the University of Toronto campus and just a few blocks North of Kensington Market, the Silver Dollar Room was originally built in 1957-58 to serve as the cocktail lounge of the Waverly Hotel, which opened its doors in 1900. One of Toronto's oldest hotels, the Waverly has since fallen into a state of disrepair. The Silver Dollar sits on the north side of the hotel, its bright red and black exterior and flashy sign in stark contrast to the Waverly's bland off-white exterior. On the south side of the hotel, identified only by a discrete sign over its entrance and stretching underneath the Waverly, is the Comfort Zone, a venue that will be discussed in the next section (Figure 1). A door on the north end of the Comfort Zone connects it to the internal staircase that leads to the Silver Dollar Room.

Soon after opening, the Silver Dollar Room began holding performances of live blues music, jazz, rock, and bluegrass. Other than its brief incarnation as a strip club in the 1960s and some infamous raids by the police in the 1970s and $1980 s,{ }^{26}$ the Silver Dollar Room quickly became one of Toronto's key venues for live blues music. Although the Silver Dollar Room has a rich musical legacy that has drawn international acclaim as a home for live blues music in Toronto and has attracted a slew of well-known musicians such as Bob Dylan and Blue Rodeo, ${ }^{27}$ it has also carried local importance for Toronto's live music communities since the 1960s for its role in growing musical talent through its space, programming, and reputation as a venue that welcomes new and developing musicians from Toronto and outside of Toronto to workshop and perform their music to local audiences and to sit in with well-known musicians. ${ }^{28}$ It continues today as an important space for Toronto's indie music scene. ${ }^{29}$ 


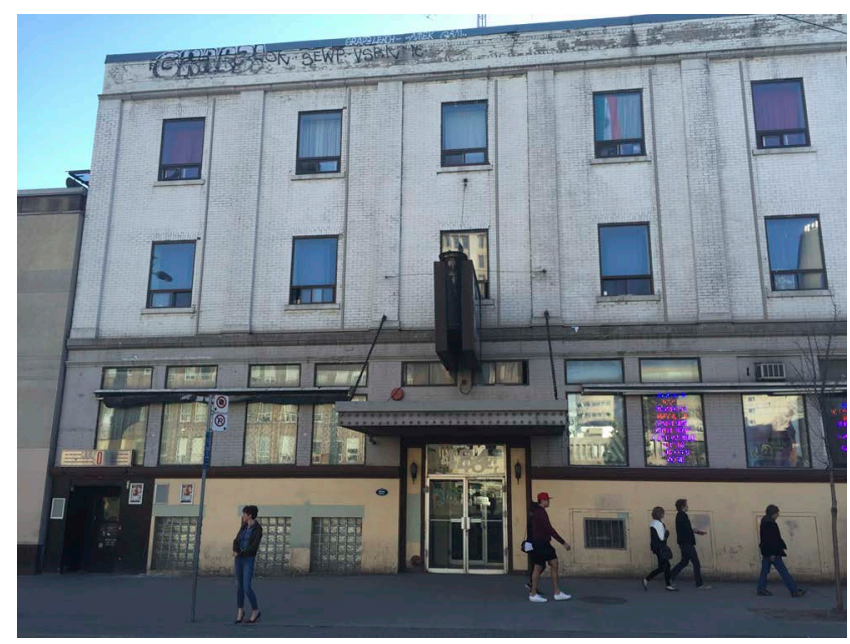

Figure 1. Full shot of Comfort Zone exterior and Waverly Hotel. @ Sara Gwendolyn Ross.

Despite its importance to Toronto's music communities, the future of the Silver Dollar Room faced the threat of a proposed amendment to Zoning Bylaw 438-86, which was proposed by the Wynn Group (the owners of both the Waverly and the Silver Dollar as well as the Comfort Zone). This proposed amendment sought rezoning in order to permit "a 22-storey mixed-use development containing 202 residential units and approximately 1,600 square metres of commercial space." ${ }^{30}$ Beyond the legal language of zoning, the amendment would have allowed the Wynn Group to replace the Waverly, the Silver Dollar Room, and the Comfort Zone with this high-rise mixed-use complex, which was intended as a private student residence for about 200 people in addition to three levels of underground parking and a replacement tavern that would likely emulate the Silver Dollar Room, but, along with other alterations, move its famous sign into the inside of the building, out of site for anyone passing by. ${ }^{31}$ However, as a result of the efforts by a series of Ward 20 (Trinity-Spadina) city councilors, such as Adam Vaughan, Joe Cressy, and Cita Ramkhalawansingh, ${ }^{32}$ cultural preservationists, and the Harbord Village Residents' Association, the Toronto City Council accorded the Silver Dollar Room cultural heritage designation on 13 January 2015, pursuant to City of Toronto Bylaw 57-2015 under Part IV, section 29 of the Ontario Heritage Act (OHA). ${ }^{33}$

The Silver Dollar Room's heritage designation is a particularly significant case study due to the unique acknowledgement of its intangible heritage value, the "use" and "function" of the space, and "its contribution to Toronto's musical culture," rather than a focus on its built tangible heritage attributes (the first criteria of the applicable Ontario Regulation 9/06), which is rare in Ontario and Toronto where heritage designations are predominantly awarded based on architectural merit. ${ }^{34}$ In the language of Regulation 9/06 and Bylaw 57-2015, the Silver Dollar Room meets the "associative and contextual value" criteria of section 29 of the OHA. The basis of the associative value determination of the Silver Dollar Room is its 
historical association with "the development and growth of music in Toronto, particularly the genres of jazz, blues, rock and bluegrass, from the 1950s through to the present day," its role as "an incubator for musical talent," its "international reputation that allowed local bands to be booked internationally," and the important musicians associated with its space. ${ }^{35}$ The basis of its contextual value determination is its "value as a landmark in Toronto by virtue of it being a well-known, long-standing destination for live music with an international reputation" as well as for its "important contribution to Toronto's musical scene."36 Picking up on the venue's importance to the community rather than its architectural merit, the statement of cultural heritage value within the designating Bylaw 57-2015 notes the relevance of the Silver Dollar Room's cultural heritage value for its frequent role as a "workshop for new and sometimes struggling musicians, both local and transient, to sit-in with more established musicians, to develop their music and build up a following." 37

The heritage protection afforded by Bylaw 57-2015 created a barrier to the redevelopment of the Silver Dollar Room's space by requiring the owner of the newly designated property under the OHA's section 29 (the Wynn Group, in the case of the Silver Dollar) to apply to the council of the municipality within which the property is located in order to seek written consent for demolition. ${ }^{38}$ Fortunately for the Silver Dollar, the Toronto Planning Department's preliminary report, along with other reports, did not receive the Wynn Group's application and development proposal favorably, ${ }^{39}$ leading the Toronto and East York Community Council to reject the proposal in early 2014 for a number of reasons but generally because " $[\mathrm{t}]$ he proposed density, building height, and lack of transition [did] not reinforce or respect the physical character of the existing neighbourhood," thus contravening the intentions of the City of Toronto's Official Plan. ${ }^{40}$

The Wynn Group appealed the decision to the OMB, and, on 8 May 2015, the appeal ended in a settlement agreement between the City of Toronto and the Wynn Group that included a reduction in the height of the proposed development from 22 stories to 15 stories and, based on its heritage status designation, mandated the preservation of the Silver Dollar Room along with the intangible cultural heritage and high use-value of the space. ${ }^{41}$ The new development will maintain the current space of the Silver Dollar Room as it is now (along with its iconic sign) and will be constructed in a manner that will highlight the built form of the Silver Dollar Room. ${ }^{42}$ The Silver Dollar Room will also have its original mural and photographs of musicians reinstated, along with the installation of a new plaque recognizing the heritage resources represented by and within the space. ${ }^{43}$

The Waverly Hotel was included in the original request for heritage designation for the Silver Dollar Room's property, but the board recommended that the Waverly portion of the property undergo further review. ${ }^{44}$ Although it received a full assessment, and despite the objections of the Harbord Village Residents' Association and the Ward 20 city councilor, the final decision did not find that the Waverly Hotel portion of the property met the requisite heritage criteria for a section 29 heritage designation under Ontario Regulation 9/06. ${ }^{45}$ 


\section{Comfort Zone}

The Comfort Zone faces an entirely different future than the Silver Dollar Room, as its space is destined to eventually become the parkade for the Wynn Group's student-oriented mixed-use housing complex described above. ${ }^{46}$ And, contrary to the Waverly Hotel, the Comfort Zone was not included in any of the heritage designation requests or heritage assessments. The Comfort Zone is an infamous Toronto afterhours electronic music venue and dance space that opened in 1997, and it is one of the few remaining venues of this format in Toronto, known by many who have spent time within its walls over the years as a Toronto afterhours "institution." 47 The venue is accessed via a simple entrance on the south side of the Waverly Hotel, which leads down a set of stairs to a large cavernous space for dancing that stretches underneath the Waverly and connects to a set of stairs on the north side, which is then linked to stairs leading upstairs to the Silver Dollar Room. On some nights, the Comfort Zone will open up access to the staircase and utilize the Silver Dollar Room as an additional room for another disc jockey (DJ) where alcohol can be served and consumed within the confines of the Silver Dollar Room.

The space operates as a electronic dance music event space with DJs spinning a variety of genres that usually lean heavily towards house music, is open predominantly on the weekends, and has deep ties with the underground dance music community and afterhours scene/subculture. ${ }^{48}$ Like most afterhours dance and music spaces, it has no liquor license, does not serve alcohol (although at one point it did), and is seen as a haven for dancing. The crowd at the Comfort Zone is a varied blend of individuals from different walks of life and with no precise demographic, except for the element that unites them - they are all there to dance and nearly everyone does. The musicians and artists that frequent the Comfort Zone also view it as a space for past and present DJs to develop and hone their craft. ${ }^{49}$ As one of the DJs whose career was founded within the walls of the Comfort Zone describes it, "[i]t was a magic zoo that we called home ... Even after traveling the whole world, Comfort Zone is still untouchable for me. This place moulded who we are today as people and DJs." 50

The case of the Comfort Zone is relevant here for three key points. The first is that the upcoming loss of this space is at odds with the desire to grow and celebrate Toronto's music culture as part of its Music City initiative. Directly attached and under the same threat as the saved Silver Dollar Room, it is an established music venue that has importance and a high use-value to sections of Toronto's music subcultures and minority music communities. It also functions as an available space for Toronto's musicians to hone their craft and for local audiences to experience both the sounds of local musicians and international guest DJs. Second, much of the language used to describe the intangible heritage merits that led to the Silver Dollar Room's heritage designation also appears in how the music subcultures and communities who attend and participate within the Comfort Zone's space describe its relevance to their experience of music in Toronto. However, third, and what is most striking, is that throughout the unsuccessful heritage designation inquiry that the Waverly Hotel underwent, and the 
successful heritage designation decision acquired by the Silver Dollar Room, no public mention, inquiry, or reference was ever made about the Comfort Zone space, and no attempt was made to engage with its soon-to-be-displaced community that occupies the space regularly but at the invisible hours of the day-night continuum.

Like Toronto's many other venues that have disappeared silently over the years, and as one of the very last (and, arguably, the last "traditional") afterhours music and dancing space, the Comfort Zone's disappearance will leave a void in the city for those who have occupied, used, and enjoyed its space. The matter of consulting with these kinds of communities affected by redevelopment decisions, or the potential of there being intangible cultural heritage merit within these kinds of spaces regardless of the tangible heritage merit, has simply never been raised - even while Music City initiatives seek to celebrate Toronto's music heritage and provide spaces for it to grow.

\section{The Guvernment and the Waterfront}

The redevelopment of Toronto's waterfront is one of the city's most talked about and heralded redevelopment megaprojects and also a project where the arts, culture, and Creative City redevelopment approaches, in general, have played, and continue to play, a formative role. ${ }^{51}$ The East Bayfront Precinct redevelopment forms a central part of Toronto's rejuvenation plan and comprises the area where the Guvernment Entertainment Complex was located until its demolition in early 2015 (Figure 2). This project is managed by Waterfront Toronto ${ }^{52}$ and was integrated into Toronto's 2006 Official Plan, governed by the 2003 Central Waterfront Secondary Plan, and further developed in the East Bayfront Precinct Plan. ${ }^{53}$ The space occupied by the Guvernment was privately owned and was not part of the specific sections of land owned by Waterfront Toronto that are undergoing Toronto's planned rejuvenation. Rather, the new "Daniels Waterfront-City of

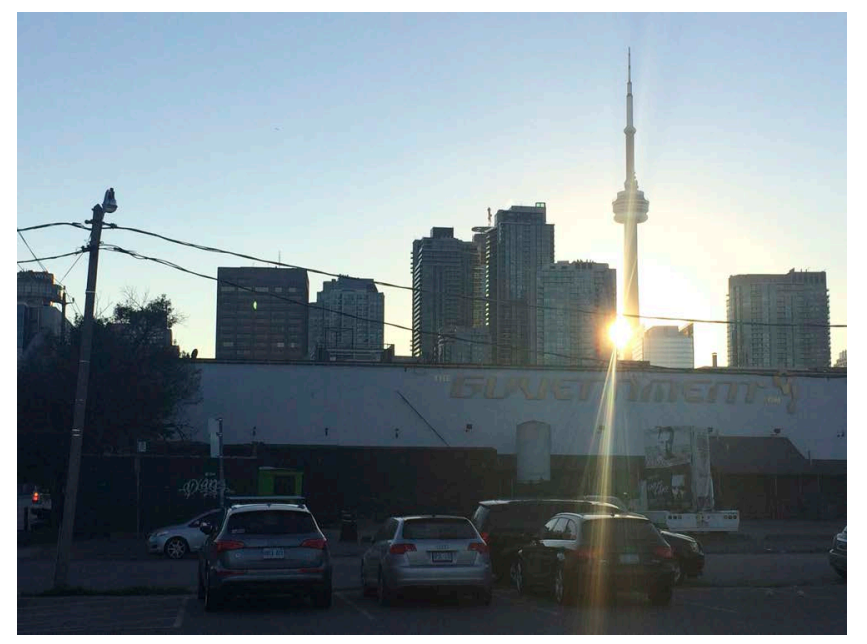

Figure 2. The Guvernment Nightclub from a nearby parking lot, with the CN Tower in background. (c) Sara Gwendolyn Ross. 
the Arts" development that will replace the Guvernment is designed to complement Toronto's newly rejuvenated and cleansed "creative" waterfront vision. ${ }^{54}$

One must only look to the current mayor John Tory's statement at the unveiling of the plans for the new development to see the excited blessing the private development has received from the city:

The revitalization of our waterfront is one of Toronto's most exciting and challenging urban renewal projects. The Daniels Corporations vision for the former entertainment complex site [Guvernment] is a groundbreaking project that will have a lasting cultural legacy. Not only will this site feature landmark residential and office towers, but it will also be home to student innovation and a hub for the creative industries. The project will complement the future East Bayfront community, further adding to the diversity of our waterfront while creating jobs that are central to our city's growth. ${ }^{55}$

The Guvernment was a large warehouse-style music complex, the largest indoor nightclub in Canada and characterized by a number of divided performance spaces of various sizes that could host a number of shows simultaneously. ${ }^{56}$ The Guvernment portion of the space was known for its sound and light design and the size of the no-frills Kool Haus warehouse-style portion of space, and it filled an important gap in Toronto's available music venues, with an attendee capacity of 2,000-3,000 people, which is an ideal capacity for large indoor music events larger than what a large nightclub can hold but not as large as a stadium. ${ }^{57}$ While the Guvernment itself opened in 1996, a similar venue, RPM and its sister venue, the Warehouse, had operated in the space since 1985, and, even before that, the space had operated for a few years as the Fresh Restaurant and Nightclub. ${ }^{58}$

The Guvernment was often open until 7 am or later and was known for its wellattended music events, its role in developing Toronto's local electronic music and electronic music scene, and its nearly 20 -year, prolific contribution to Toronto and Canada's international music reputation. In terms of more marginal music subcultures, the Guvernment was a key venue in the development of Toronto's and Canada's “drum 'n' bass" musical subculture and existing minority music community, which is characterized by bass-heavy music in the $160-80$ beats per minute range. The Guvernment's history has seen a plethora of key modern performers, much longer than that of the Silver Dollar Room. Its history and relevance is succinctly summarized on the sales website for the new Daniels development that will replace it:

The club finally closed its doors on January 31st, 2015. Formerly the RPM nightclub for about 10 years which brought legends like the Beastie Boys and made former Jamaican born Canadian DJ Chris Sheppard into a superstar in the dance music world. Now currently the Guvernment nightclub which opened its doors in 1996 where superstars such as Lady Gaga and the Rolling Stones played and where DJ Deadmau 5 got his start. Charles Khaboth $[s i c]$, owner of INK Entertianment [sic] tried to buy the building with his partners but were unsuccessful as Daniels Corp. has bought it to turn the site at Queens Quay and Lower Jarvis into residential and commercial properties known as the Daniels Waterfront Condos. ${ }^{59}$ 
The sale of the Guvernment's space occurred despite its continued financial success and popularity, the vocal protests of attendees, and the venue owner and operator's attempts to purchase the space in order to save it (although his attempts did result in a year-long extension of the Guvernment's lease on the space). ${ }^{60}$ Keeping in mind Toronto's Music City project that calls for and encourages spaces for local music production, performance, and consumption and requires large venues for attracting well-known artists and providing the space for enough attendees to leverage these artists' performance fees - the kind of space the Guvernment provided-one might wonder at the rationale behind replacing the Guvernment with the Daniels development, which the mayor proposes "will have a lasting cultural legacy" without any investigation into the existing intangible cultural heritage merits of the property. ${ }^{61}$

However, as we saw with the Comfort Zone, these kinds of questions have not played into the redevelopment decisions affecting Toronto's musical vibrancy, music heritage, and intangible culture and the music communities affected by these decisions. Beyond the owners of the buildings and the physical neighbors of the space, these stakeholders were not consulted. While heritage considerations have figured into the designs for Toronto's waterfront renewal, the applicable planning documents do not address the different kinds of intangible cultural heritage that may exist in a city and glaze over the use-value that exists within cultural spaces that make up, or used to make up, the waterfront area. ${ }^{62}$ The failure to consider the existing intangible cultural heritage within the waterfront space demonstrates a faulty assessment of social impact in order to effectively measure the competing values and interests of the various cultures and communities either culturally and/or economically invested in the space. ${ }^{63}$ Such consideration is in contrast to the acknowledgement and protection of the Silver Dollar Room's intangible cultural heritage merits, use-value, and live music assets, which occurred 13 days before the Guvernment closed for good.

The oversights surrounding the Guvernment's demolition are additionally illustrated by the mayor's excursion to study the live music culture of Austin, Texas, that occurred around the same time as the redevelopment plans for the Guvernment's space were announced. Upon the mayor's return, in response to his trip and just days before he spoke glowingly at the unveiling of the plans for the "Daniels Waterfront-City of the Arts" that will replace the Guvernment, he expressed his "determination to more fully integrate music into the cultural and economic fabric of the city." 64 Yet, as we have seen, the Guvernment represented the same kind of large, iconic, internationally respected live music venue that is an asset in developing a fuller cultural and economic integration of music into the fabric of Toronto and the kind of music space and culture that the mayor went to investigate and learn about in Austin.

\section{Brunswick House and Albert's Hall}

Located at 481 Bloor Street West, on the outer edge of Toronto's Harbord Village and bordering on Toronto's Annex neighborhood, the 140-year-old Brunswick House closed in April 2016. Found in the same neighborhood as the Silver Dollar 
Room, it has been listed as a heritage property since 17 September $1991 .{ }^{65}$ While its tangible heritage merits have played into negotiations as to how the space will be redeveloped into a pharmacy drugstore chain called Rexall, and even though residents in the area have "expressed concerns about losing The Brunswick House's rich heritage_-it's been a working class tavern, a noted jazz venue, and a gathering place for local literary lions," preserving the intangible culture, music assets, and cultural capital of the space has not figured into the redevelopment plans and is not protected by the building's existing heritage listing. ${ }^{66}$

Unlike the Silver Dollar, or the Comfort Zone, the Brunswick House had shifted from the musical offerings that made it famous and, although operating as a music venue, had become mostly known as a relatively generic nightclub operating on the weekends, popular with a young adult demographic and university students from the nearby University of Toronto campus and often the object of the neighboring resident's complaints about noise and "disruptive" nighttime behavior. Nonetheless, the Brunswick House's musical legacy and history as a community gathering space stretches far back. Starting out as a tavern in 1876 that primarily served the local community, the Brunswick House continued on as a neighborhood institution into the 1970s when it also became popular with students - as it was when it closed. As the foreword to a 1975 poetry book written about the Brunswick House reads, "[a] community like this doesn't need a 'club, ... it develops, indeed evolves, the classical meeting place in the classical Greek manner. The Brunswick House is this meeting place."67

Like the Silver Dollar Room, the Brunswick House originally served as a hotel bar to the hotel above its space, a space that would eventually become a flophouse prior to ceasing operations entirely as a hotel. ${ }^{68}$ As far as its musical past, the Brunswick House struggled to have live music during the 1930s when Ontario's Liquor Control Board was known to restrict amenities provided by venues serving alcohol, such as live music, which were seen to stimulate alcohol consumption. ${ }^{69}$ Contrary to the requests of "respectable" hotels to have live music, such as "tasteful trios playing on weekend evenings," the requests from hotels like the Brunswick House with rougher reputations were not often granted. ${ }^{70}$ While the Brunswick House was known in the 1960 and 1970s for performances by the Annex neighborhood's quirky and eccentric characters that famously comprised its neighborhood fabric, and as the site of LGBTQ community activism, and even as home to a syndicated television series, ${ }^{71}$ the Brunswick House really hit its stride for live music in the 1970 s and especially as the 1980 s came about. ${ }^{72}$ During this period, the Brunswick House became intimately linked to its newly opened upstairs space: Toronto's legendary jazz and blues bar, Albert's Hall. After Albert's Hall opened in the 1970s, in conjunction with the Brunswick House, acts such as K.D. Lang and blues greats such as Albert King, Etta James, Howlin' Wolf, Buddy Guy, and Muddy Waters frequently performed in the space. ${ }^{73}$

While the Brunswick House continued as a music and dance venue up until its closure, Albert's Hall eventually became an unremarkable tele-theater/off-track betting venue and, like the Brunswick House, is slated to be replaced by the Rexall 
development. ${ }^{74}$ While some nearby residents were concerned with preserving the intangible cultural heritage merits and music assets that were germinated within the Brunswick House's space over the years, ${ }^{75}$ there are also many who were happy with the news of its closure, such as the Chair of the Harbord Village Resident's Association (the same association that fought for the Silver Dollar Room's intangible cultural heritage and heritage designation). ${ }^{76}$ While the Silver Dollar Room has its share of past misdemeanors and a history of disruptive behavior, critics of the Brunswick House's continued existence highlight "that while there are many people who remember the 'The Brunny's' golden years, when it was filled with university students and live musicians like Jeff Healey, in recent years police have been constantly called to the bar and there's a regular spillover on to the street after the bar closes around 2 a.m."77

While the protection of the tangible heritage elements of 481 Bloor Street West identified in the 1991 heritage listing of the building must be addressed within Rexall's redevelopment plans, the original listing focuses on the built merit of the space and does not include reference to, or protection for, the intangible cultural heritage merits of the space-such as the musical culture within its walls - meaning that these characteristics can be effectively ignored as redevelopment occurs. ${ }^{78}$ In the foreword to that 1975 poetry book on the Brunswick House, one can find the proud statement: "For fifty years the Annex Ratepayers Association has tried to keep this area-in spite of developers, city planners and others - as a refuge for humans, for people." "I9 It seems like the battle here, however, was finally lost, even while the building was listed as a heritage property and even though Toronto's Music City strategy purportedly seeks to embrace the city's music heritage and intangible culture that has grown in historic spaces like the Brunswick House over the years. The case of the Brunswick House highlights the importance of the heritage designation process (as opposed to only listing a building on the Heritage Register), and why it is important to look into the intangible cultural heritage merits of a space during cultural heritage designation efforts and decision-making processes since, without this, heritage designation or listing based upon built merit cannot serve effectively to protect the historic culture and communities within the buildings.

\section{BALANCING CONFLICTING NOTIONS OF VALUE AND THE RECOGNITION AND PROTECTION OF SPACES OF INTANGIBLE CULTURAL HERITAGE}

As the 2013 Burra Charter notes in Article 5.1: "Conservation of a place should identify and take into consideration all aspects of cultural and natural significance without unwarranted emphasis on any one value at the expense of others." 80 There are a number of ways of looking at the value or merit housed within a cultural space in the city. As we have seen, there is the tangible value or merit as well as the intangible - where intangibility tends to be a less acknowledged element. There is also a tension between the use-value of a space and the exchange-value of a space, but even more relevant to the subject of this article, there is the need for intergenerational 
equity in assessing what constitutes heritage value for divergent groups and generations and what should be protected.

In terms of balancing the diverse and often diverging interests that exist simultaneously within the space, it is problematic when redevelopment decisions and strategies are deployed counteractively, such as the redevelopment of key music venues, while a vibrant Music City steeped in the city's musical history is also potentially being established. Article 26.3 of the Burra Charter outlines the balancing process that should be applied in order to remove the centrality of commodity and market orientation in heritage decision making:

Groups and individuals with associations with the place as well as those involved in its management should be provided with opportunities to contribute to and participate in identifying and understanding the cultural significance of the place. Where appropriate they should also have opportunities to participate in its conservation and management. ${ }^{81}$

\section{Intangible Cultural Heritage Protection in Canada and Determining What Is Valuable}

The reason that the Burra Charter is particularly relevant in this discussion is that the Canadian Register of Historic Places (CRHP) has adopted the Burra Charter's definition of "heritage value" (used interchangeably with "cultural significance" in the Burra Charter)— "the aesthetic, historic, scientific, cultural, social or spiritual importance or significance for past, present or future generations" 82 — and has recognized the Burra Charter to be "an internationally accepted statement of principles that provides guidance for the conservation and management of places of cultural significance." 83 By using the Burra Charter's definition of heritage value as a soft regulatory mechanism, the guidance it provides via its practice note in interpreting and deploying this definition (which includes an equitable treatment and valuation of intangible cultural heritage) is thus also applicable in the Canadian context, despite Canada's dearth of hard regulations dealing with intangible cultural heritage. ${ }^{84}$ In seeking heritage designation status, the CHRP provides national guidance for crafting the requisite statement of significance that will include the information assessed at the provincial level in an Ontario Section 29 OHA heritage designation, for example, through Ontario Regulation 9/06's “criteria for determining cultural heritage value or interest." 85 A building or space that receives heritage designation at the municipal and provincial level will eventually also be listed by the CHRP.

While Canada has yet to ratify the 2003 UNESCO's Convention for the Safeguarding of Intangible Cultural Heritage (UNESCO Convention) and has not implemented any specific programs or policies explicitly designed to safeguard intangible cultural heritage ${ }^{86}$ — with the limited provincial exceptions of Quebec and Newfoundland and Labrador as well as the acceptance of the Burra Charter's heritage value definition ${ }^{87}$ - the notion of intangible cultural heritage can be applied in Canada by reading intangibility into the existing 
frameworks to protect tangible cultural heritage. ${ }^{88}$ We saw this with the Silver Dollar Room where the "associative" and "contextual" heritage criteria set out in Ontario Regulation 9/06 were used to argue that the elements of intangible musical culture and heritage within the space of the Silver Dollar Room were worthy of cultural heritage protection. In addition, the CHRP's national guide for determining heritage value-through importing the Burra Charter's definition of heritage value-also incorporates the Burra Charter's well-developed insistence on including intangibility into heritage value determinations.

While these frameworks theoretically establish the potential for equally valuating intangible and tangible heritage, modern heritage intangibility concerns are not being effectively examined within redevelopment decisions due at least partly to preconceived notions of what constitutes heritage. As we saw with the above case studies, elements such as the comparative age of a venue, its disruptive presence in a neighborhood, and the potential exchange-value gains that can be maximized through replacement or redevelopment can be barriers to preservation considerations. As the Burra Charter's "Practice Note: Understanding and Assessing Cultural Significance" warns, it is important to avoid preconceptions in heritage determinations:

A place can be culturally significant regardless of its age, notions of conven-
tional beauty, or the presence or absence of built form, or the number of
people for whom it is significant. A place does not have to be "old" to be his-
torically or socially significant, nor conventionally beautiful to be aesthetically
significant. Places with no visible physical evidence can still be highly signif-
icant. In assessing cultural significance, it is essential to be open to knowl-
edge and values expressed from different perspectives and cultural contexts.
Be prepared to conduct deeper research beyond "the mainstream."

This warning lines up with seminal research reports out of the Getty Conservation Institute that acknowledge that different kinds of value or values can exist within a heritage space and that these different and often conflicting values of stakeholders in the space must be engaged within heritage preservation assessments and decisions without allowing one kind of value to dominate to the detriment of other values. ${ }^{90}$ More importantly though, avoiding preconceptions as to what merits heritage preservation and ensuring openness to alternate conceptions of value and cultural significance are gestured to in the 2011 recommendations compiled by Heritage Toronto and the Toronto Historical Association that note a "lack of emphasis on, and protections afforded at the provincial level to intangible heritage resources"91 and call on Toronto and local heritage organizations "to update their perspective and broaden their scope in order to reflect a more diverse definition of 'heritage', one that includes intangible heritage resources, cultural landscapes and natural heritage resources as well as built heritage." 92

\section{Use-Value versus Exchange Value}

A useful way of viewing the interplay and clash of values in the context of city redevelopment projects, culture, music, and the various related stakeholders is through a 
use-value/exchange-value framework. Harvey Molotch and John Logan draw on the "Marxian lexicon" to propose an analytical framework that draws on the "exchange value" and "use value" of a place in a manner designed to speak to the urban development context. ${ }^{93}$ "Exchange-value," in this context, refers to "the utilization of property to generate profit," while "use-value" refers to "values individuals assign to property that do not enter into commodity exchange." 94 Use-value and exchangevalue may or may not overlap and coexist within the physical boundaries of tangible space. ${ }^{95}$ These overlaps in values within the same physical boundaries and tangible space can create an antagonistic relationship between the contrasting and conflicting value interests of stakeholders, which calls to mind Brian Graham, Gregory Ashworth, and John Tunbridge's description of the inherent dissonance of heritage where: " $[\mathrm{H}]$ eritage is both a cultural and an economic good and is commodified as such. This multiple use and consumption occurs with virtually all heritage and is a potent source of conflict between the various interest groups involved." 96

Intangible cultural heritage is interconnected with the use-value of a space where intangible cultural heritage can be generated and exist within a space of high community use-value, regardless of the exchange-value the space may or may not carry. Within Toronto's redevelopment projects, the exchange-value merit or potential of a space often overwhelms considerations of the use-value housed within the same space, which can be observed with the types of projects or private developer interests that are replacing the disappearing music venues described above. However, as expressed by the Burra Charter, as well as by Marta de la Torre and Randall Mason in their work for the Getty Conservation Institute, situations where one kind of value overpowers other(s) must be carefully managed and questioned for who and how these decisions are being made. ${ }^{97}$

Laam Hae underlines a marked "disappearance of spaces for transgressive and alternative subcultures," such as live music venues and spaces for nighttime experiential production and consumption in today's post-industrial cities that signifies "a serious decline of people's rights; that is, people's rights to appropriate urban space and participate in producing it for the purpose of use value, play, diverse social interactions, alternative community-building and the radical re-imagining of urban society." ${ }^{\prime 8}$ Even though these kinds of spaces of high use-value can play an important role in challenging and resisting the dominance of the exchangevalue focus that many redevelopment projects can favor, as we have seen, without a tool like effective intangible cultural heritage protection and determination frameworks, these spaces face an often unspoken but losing battle. ${ }^{99}$

\section{Intragenerational Equity, Intergenerational Equity, and Intertemporal Distributive Justice as Part of Sustainable Development in the City}

As the vice-president of public affairs at Music Canada, Amy Terrill asks: "Could it be that if you do not protect, celebrate or nurture your past music history, 
you cannot hope to maintain or grow a successful current music scene? Does a lack of respect for the past lead to instability in the present and future?"100 This prescient statement speaks to the fundamental role of time in heritage, where heritage is "a view from the present, either backward to a past or forward to a future" but where the three tenses of past, present, and future are intimately connected and overlapping. ${ }^{101}$ Within urban redevelopment strategies seeking global recognition and economic gains_-as Toronto's processes display-views of present heritage spaces forward to the future often suffer from an overemphasis of present and future projections of the exchange-value merits over present use-value merits and the cultural importance of a space, in addition to a failure to effectively consider without prejudice future projections of the use-value merits of a space, which are inherently difficult to measure. ${ }^{102}$ While this oversight may seem unimportant or go unquestioned in the present, where spaces of intangible cultural heritage are destroyed, the consequences are irreversible but, again, largely invisible and unquantifiable. ${ }^{103}$ As Gail Higginbottom and Philip Tonner warn, “just because a site has little relevance now does not mean it won't have any for future generations, who could well be astonished as to why we allowed the destruction of places that presently 'do not appear to have any value to anyone."'104

In applying sustainable development principles to the cultural heritage context, where "a key element of this concept is equity in the treatment of different generations over time," David Throsby draws on the terms "intergenerational equity" and "intertemporal distributive justice" in order to "to refer to fairness in distribution of welfare, utility, or resources between generations."105 The Burra Charter's preamble also picks up on this notion: "These places of cultural significance must be conserved for present and future generations in accordance with the principle of inter-generational equity."106

Along with intergenerational equity, Throsby emphasizes the importance of intragenerational equity, which additionally speaks to the diversity of values and stakeholders affected by city redevelopment processes who may not be adequately consulted, or considered, in redevelopment decisions. Intragenerational equity "refers to equity in access to the benefits of cultural capital across social classes, income groups, locational categories, and so on." 107 Finally, as Throsby goes on to note,

[i]t may be appropriate for stakeholders affected by the decision to have some input into these processes. This concern raises the matter of empowerment of those whose interests are affected by heritage decisions; general considerations of sustainability would suggest attention to the fairness of decision-making procedures in this context. ${ }^{108}$

Discussing the future importance of heritage and the dilemma that presents itself between present and future consumption again highlights the need for better consultation with the affected stakeholders, the divergent and often 
dissonant values that can exist within a space, and the effective acknowledgement of the use-value and intangible cultural heritage merits that can be bound up in spaces targeted for redevelopment. ${ }^{109}$ The future is even more difficult to predict without thorough assessment of who will be affected by decisions and how. In looking back at Toronto's Music City and redevelopment strategies, it would seem that greater regard for the diversity of values-whether framed as intangible cultural heritage or use-value-would lead to development that is more aligned with a sustainable approach to cultural development that accounts not only for inter- and intragenerational equity but also, more generally, for a more equitable city.

\section{CONCLUSION}

While live music venues and spaces of nighttime culture have an unfortunate history of silently disappearing into the night at the mercy of redevelopment projects, the mechanics of how this occurs plays out in the context of municipal legal frameworks and municipal zoning and planning practices. As such, attempts to preserve the use-value and intangible cultural heritage embodied within these spaces are best approached through an engagement with these same frameworks. The Silver Dollar Room is not only a step in the direction of a more equitable weighing of conflicting interests and valuation in the future of existing spaces of intangible and tangible cultural heritage and high cultural use-value, but, hopefully, it is only the beginning of Canada and Ontario's growing concern with live musical culture and its associated spaces where profit motives and commercial objectives are no longer accepted as the leading concern in city redevelopment, and urban inclusion is prioritized. ${ }^{110}$

The Silver Dollar Room represents an example where provincial legislation governing municipal heritage management was able to step in and contribute to the preservation of an invaluable element of Toronto's rich musical culture, something that is being rapidly lost with the closure of similar and even adjacent venues. Zooming out to a federal level, the ratification of the UNESCO Convention could be a helpful step in facilitating the creation and application of intangible cultural heritage protection within Canadian cities in order to better account for the use-value within certain spaces of culture. This could in turn provide more effective integration of the lived cultural practices of a city in municipal planning and municipal legal frameworks by focusing on already existing elements of intangible lived culture that are generated in an organic manner (maintaining the use-value of a space) rather than in a planned manner with spaces strategically designed to germinate what is deemed by urban governance and planning actors and Creative City planning documents to be "cultural" or "creative" in order to attract a particular "class" of peoplethe creative class- thus prioritizing market rationality over concerns with usevalue, heritage value, and cultural significance. ${ }^{111}$ 


\section{ENDNOTES}

1. Berman 2015, v.

2. Zukin 2010, 11 .

3. These questions are also linked to our understanding of what constitutes "culture," which is beyond the scope of this article, although increasingly expanded notions of what constitutes culture are certainly linked to increasingly expanded notions of what constitutes "heritage." Handler 2003, 357-59.

4. "Legal complexes" include "the assemblage of legal practices, legal institutions, statutes, legal codes, authorities, discourses, texts, norms, and forms of judgement." Rose and Valverde 1998, 542; see also Hae 2012, 7. For a discussion of heritage dissonance and as a site of inevitable social conflict and tension, see generally Graham, Ashworth, and Tunbridge 2000, 3-5.

5. Philippopoulos-Mihalopoulos 2007.

6. Mason 2002, 5.

7. Zukin 2010, xi, 9, 246.

8. Throsby 2010, 117.

9. Convention for the Safeguarding of Intangible Cultural Heritage (UNESCO Convention), 17 October 2003, 2368 UNTS 1; Burra Charter: The Australia ICOMOS Charter for Places of Cultural Significance (Burra Convention), 2013, Art. 1.2, explanatory note to Art. 1.2, practice note, 4-5 (from which Canada draws its definition of heritage value and cultural significance); Canada's Historic Places 2010; Canadian Historic Places, "Writing Statements of Significance" (Parks Canada), 10-11, http://www.historicplaces.ca/media/5422/sosguideen.pdf. Compare the situation in Canada's province of Quebec and Quebec's Cultural Heritage Act, RSQ 2011, c. P-9. Handler 2003, 358.

10. See City of Toronto, Culture Division, Culture Plan for the Creative City, 2003 ; Toronto Music Advisory Council, "Toronto Music Strategy: Supporting and Growing the City's Music Sector," draft for consultation, December 2015; Daniel Silver, ed., "From the Ground Up: Growing Toronto's Cultural Sector," 2011, http://www.toronto.ca/legdocs/mmis/2011/ed/bgrd/backgroundfile-41204.pdf; Strategies for a Creative City Project, Imagine a Toronto ... Strategies for a Creative City, 2006, http://web.net/ imagineatoronto/fullReport.pdf; Strategies for a Creative City Project, Toronto Case Study, 2006; AuthentiCity 2008; Foster, Kain, and Prentice 2011.

11. See, e.g., Grodach and Silver 2013, 2, who identify a "global phenomenon" where "[c]ities now routinely look to culture in its diverse manifestations - as the arts, group identity and heritage, and media and design-based industries (e.g., film, music, architecture) — as urban policy tools to address a broad array of urban issues. These range from neighborhood revitalization and community engagement to job creation, talent attraction, and achieving 'world city' status." Lehrer and Winkler 2006, 144; Oakley and O'Connor 2015, 202. See also UNESCO, "The Power of Culture: The Intergovernmental Conference on Cultural Policies for Development," 1998.

12. Florida 2002, 2005; Strategies for a Creative City Project, Toronto Case Study, 22, 36; AuthentiCity 2008; International Federation of the Phonographic Industry and Music Canada 2015, 2-3, 5-6, 42; City of Toronto, Official Plan, 2006, 3.5.2; City of Toronto, Culture Plan for the Creative City, 2003. The "creative class" is a rather ambiguous and malleable concept but can be loosely summarized as workers in art, design, and technology industries. See Grodach and Silver 2013, 4.

13. Foster, Kain, and Prentice 2011; City of Toronto, "Collaborating for Competitiveness: A Strategic Plan to Accelerate Economic Growth and Job Creation in Toronto," 2013, http:// www1.toronto.ca/static_files/economic_development_and_culture/docs/Collaborating_for_ Competitveness_FINAL-v7.pdf.

14. Interview of Michael Hollett, cited in Dave Morris, “Toronto's Music City Dream Hindered by Red Tape," Globe and Mail, 16 June 2015, http://www.theglobeandmail.com/arts/music/torontosmusic-city-dream-hindered-by-red-tape/article24981758/.

15. Music Canada, "Measuring Live Music in Canada," musiccanada.com/campaigns/measuringlive-music-in-ontario-stand-up-and-be-counted. 
16. Titan Music Group 2012. See also the Austin-Toronto Joint Music City Alliance, 3 October 2013, Appendix C, www.toronto.ca/legdocs/mmis/2013/ed/bgrd/backgroundfile-63954.pdf, which is widely touted as the world's first music city alliance agreement and established during Mayor Rob Ford's tenure (Ben Rayner, "John Tory Gets a Great Vibe from Austin's SXSW Music Fest," thestar.com, 21 March 2015, http://www.thestar.com/entertainment/music/2015/03/21/johntory-gets-a-great-vibe-from-austins-sxsw-music-fest.html) and the Austin-Toronto Music City Alliance Partnership Draft Framework and Terms of Reference, November 2014, Appendix B; Toronto City Council and Committees, By-laws and Codes, http://www.toronto.ca/legdocs/ mmis/2013/ed/bgrd/backgroundfile-63954.pdf. Austin, Texas is often seen as the "live music capital of the world." See, e.g., Grodach 2013; Rayner, "John Tory Gets a Great Vibe."

17. See Music Canada, "Measuring Live Music." See also Foster, Kain, and Prentice 2011.

18. Music Canada 2013, 1.

19. Music Canada 2013, 1; Throsby 1997, 14-15, 2001, ch. 3, 2002, 103; Hutter and Throsby 2008, 5.

20. Throsby 1997, 14-15. See also Ministry of Tourism, Culture and Sport, "Ontario a Leader in Live Music: McGuinty Government Developing Live Music Strategy to Showcase Industry Globally," news release, 23 January 2013, http://news.ontario.ca/mtc/en/2013/01/ontario-a-leaderin-live-music.html.

21. Music Canada 2013, 2-3.

22. See, e.g., AuthentiCity 2008; Strategies for a Creative City Project, Imagine a Toronto; Strategies for a Creative City Project, Toronto Case Study, 22, 36; City of Toronto, Culture Plan for the Creative City.

23. Denise Benson, Then and Now: Toronto's Nightlife History (blog), thenandnowtoronto.com.

24. Heritage Toronto and the Toronto Historical Association 2011, 5. For a similar finding, see also Oakley and O'Connor 2015, 203.

25. Heritage Toronto and the Toronto Historical Association 2011, 5, n. 2.

26. Tom Beedham, "Historic Venue Spotlight: The Silver Dollar Room," Noisey (blog), 9 July 2014, noisey.vice.com/en_ca/read/historic-venue-spotlight-the-silver-dollar-room.

27. City of Toronto, Bylaw 57-2015 - to designate the property at 484 Spadina Avenue (Silver Dollar Room) as being of cultural heritage value or interest, 11 December 2014, 2. See also Ferenc 2015; Brad Wheeler, "Why the Silver Dollar is Worth Saving," Globe and Mail, 23 January 2015, http:// www.theglobeandmail.com/news/toronto/why-the-silver-dollar-is-worth-saving/article22606865/. It has also appeared in a number of films such as Adventures in Babysitting and Police Academy. Beedham, "Historic Venue Spotlight"; Toronto, Urban Design, City Planning Division, "Intention to Designate under Part IV, Section 29 of the Ontario Heritage Act - 484 Spadina Avenue," 20 March 2014, 11.

28. Bylaw 57-2015, 2.

29. Cathal Kelly, "Dan Burke: Wasted Days and Wasted Nights," thestar.com, 14 June 2009, http:// www.thestar.com/news/insight/2009/06/14/dan_burke_wasted_days_and_wasted_nights.html; Beedham, "Historic Venue Spotlight."

30. See, e.g., OMB Case No. PL131176, 1095909 Ontario Ltd. (c.o.b. Wynn Group of Companies) v Toronto (City), [2014] OMBD No. 498 (hereafter Wynn v Toronto).

31. See, e.g., Patty Winsa, "Toronto Rejects Proposal to Tear Down Hotel Waverly and Silver Dollar Room for Student Housing," thestar.com, 15 January 2014 https://www.thestar.com/news/ gta/2014/01/15/toronto_rejects_proposal_to_tear_down_hotel_waverly_and_silver_dollar_room_ for_student_housing.html ; Gregg Lintern, Director, Community Planning, Toronto and East York District, "Staff Report Action Required-484 Spadina Ave-Zoning Amendment ApplicationRequest for Direction Report," 22 November 2013, 3; Richard Longley, "Waverly Goodbye," NOW Toronto, 17 June 2015, https://nowtoronto.com/news/waverly-goodbye/.

32. Toronto and East York Community Council, Agenda Item, 11 September 2011, http://app. toronto.ca/tmmis/viewAgendaItemHistory.do?item=2011.TE9.93. Letter from Adam Vaughan to the Toronto and East York Community Council, 8 September 2011; letter from Sue Dexter to the Toronto Preservation Board, 16 July 2014; letter from Ceta Ramkhalawansingh to the Toronto Preservation Board, 16 July 2014. To clarify, the Harbord Village Residents' Association represents those who live between College and Bloor and Spadina and Bathurst. 
33. Bylaw 57-2015. Ontario Heritage Act (OHA), RSSO 1990, c. O-18.

34. Bylaw 57-2015.

35. Bylaw 57-2015, 2.

36. Bylaw 57-2015, 2.

37. Bylaw 57-2015, 2.

38. OHA, s 34(1); Leslie Ferenc, "Silver Dollar Room Now a Heritage Site," thestar.com, 13 January 2015, https://www.thestar.com/news/gta/2015/01/13/silver_dollar_room_now_a_heritage_site.html

39. “484 Spadina Avenue - Zoning Amendment Application, Staff Report Action Required,” 19 August 2013. See, e.g., Lintern, "Staff Report Action Required.”

40. “484 Spadina Avenue - Zoning Amendment Application,” 11. See also City of Toronto, Official Plan.

41. Winsa, "Toronto Rejects Proposal"; Wynn v Toronto. See also letter from Mark Flowers at Davies Howes Partners LLP to Toronto and East York Community Council, 14 January 2014.

42. Codi Wilson, "Silver Dollar Will Live on as Live Music Venue," CP24, 8 May 2015, http:// www.cp24.com/news/silver-dollar-will-live-on-as-live-music-venue-1.2365609; Justin Skinner, "OMB Settlement a Good Deal for Spadina and College Neighbourhood," InsideToronto.com, 12 May 2015, http://www.insidetoronto.com/news-story/5614271-omb-settlement-a-good-deal-forspadina-and-college-neighbourhood/; Letter from Joe Cressy (Ward 20 City Counsellor), Ausma Malik (Toronto District School Board Ward 10 Trustee), and Tim Grant (Chair of the Harbord Village Resident's Association) to neighbourhood residents re: "Resolution on 484 Spadina Avenue (the Waverley and Silver Dollar Room)," 8 May 2015.

43. City Council Decision re: 484 Spadina Avenue: Zoning By-law and Site Plan Appeals, adopted 5 May 2015.

44. Toronto Preservation Board, "Recommendation re: Intention to Designate under Part IV, Section 29 of the Ontario Heritage Act - 484 Spadina Avenue," 31 March 2014.

45. Harold Madi, Toronto, Director Urban Planning, City Planning Division, "Heritage Evaluation 484 Spadina Avenue - Waverly Hotel, Staff Action Report Required," 23 June 2014; letter from Sue Dexter to the Toronto Preservation Board, 16 July 2014; letter from Ceta Ramkhalawansingh to the Toronto Preservation Board, 16 July 2014.

46. Longley, "Waverly Goodbye."

47. For an example of personal anecdotes related to the space, see, e.g., Frankenraver, "Rave Reviews-The Comfort Zone,” Frankenraver: reprazentin 4 da ol skool (blog), 10 November 2011, https://frankenraver.wordpress.com/2011/11/10/rave-reviews-the-comfort-zone. Paul AguirreLivingston, "The Night Shift: Into the Comfort Zone," The Grid, 6 February 2012 (originally published in the now defunct The Grid, but available in replicated form, see post no. 1621, http://www.tribemagazine. com/board/tribe-main-forum/143940-comfort-zone-raided-morning-65.html).

48. See, e.g., Lee Trotter, "Afterhours in Toronto: A Look Inside Comfort Zone," 6am Group, 25 August 2015 http://www.6am-group.com/hours-toronto-look-inside-comfort-zone; see also Comfort Zone website, comfortzonetoronto.com.

49. See, e.g., Trotter, "Afterhours in Toronto."

50. Interview of Carlo Lio, reprinted in Trotter, "Afterhours in Toronto." For an account of some of the Comfort Zone's prior run-ins with the law, see Jackson Hayes, "33 Arrested in Club Raid, Drugs Seized,” thestar.com, 17 March 2008, https://www.thestar.com/news/gta/2008/03/17/33_ arrested_in_club_raid_drugs_seized.html. But compare Benjamin Boles, "Revenge of the Comfort Zone: Good Luck to the Comfort Zone in Its Suit against the City,” NOW Toronto, 12 March 2009, https://nowtoronto.com/music/revenge-of-the-comfort-zone/.

51. Patterson and Silver 2015, 269, 273. For additional information, see Waterfront Renewal on the City of Toronto's website, http://www1.toronto.ca/wps/portal/contentonly?vgnextoid= 8c48e26b1af51410VgnVCM10000071d60f89RCRD, the Waterfront Toronto website, http://www. waterfrontoronto.ca, and the site-specific plans for East Bayfront, http://www.buildeastbayfront. com.

52. See Waterfront Toronto, http://www.waterfrontoronto.ca. Lehrer and Laidley 2008, 791. 
53. All of these plans are available at http://www1.toronto.ca.

54. This includes increased mixed-use residential space, notably to attract nearby downtown office workers and creative industry workers, such as those seeking live/work spaces. See the City of Toronto, Official Plan, s. 2.2.1. See also AuthentiCity 2008; Foster, Kain, and Prentice 2011; David Shum, "Daniels Corporation Unveils Waterfront Mixed-Use Condo Project," Global News, 26 March 2015, http://globalnews.ca/news/1904704/daniels-corporation-to-unveil-waterfront-mixed-use-condoproject. City of Toronto, Culture Plan for the Creative City.

55. "Groundbreaking Plans Unveiled for Daniels Waterfront - City of the Arts at Former Guvernment Entertainment Complex,” Business Wire, 26 March 2015, http://www.businesswire. com/news/home/20150326006250/en/Groundbreaking-Plans-Unveiled-Daniels-Waterfront---City. See also the planning application for the Daniels Waterfront development: Application no. 14249503 STE 28 SA for 142 Lake Shore Blvd East, Toronto Development Projects; Shum, "Daniels Corporation Unveils Waterfront."

56. Benson 2015, 513.

57. Benson 2015, 496.

58. Benson 2015, 159, 495.

59. "Waterfront Condos by Daniels Corp," Daniels Waterfront Condos, danielswaterfrontcondos.ca.

60. Benson 2015, 513.

61. "Groundbreaking Plans Unveiled for Daniels Waterfront."

62. See, e.g., Toronto Culture, "Canada's Urban Waterfront: Waterfront Culture and Heritage Infrastructure Plan,” 2011, http://wwwl.toronto.ca/wps/portal/contentonly?vgnextoid=0fc91ba53b 450410VgnVCM10000071d60f89RCRD.

63. Winthrop 2002, 174.

64. Rayner, "John Tory Gets a Great Vibe."

65. City of Toronto, "Heritage Preservation, Heritage Property Detail," app.toronto.ca/ HeritagePreservation.

66. Note that, here, heritage listing is distinct from heritage designation. The latter confers a property with legal status under the 1990 Ontario Heritage Act whereas the former simply means that Heritage Preservation Services will assess proposed development and building applications. Annemarie Brissenden, "Brunswick on the Block," Gleaner Community Press, 5 December 2015; Annemarie Brissenden, "The Brunswick House Has a Tenant," Gleaner Community Press, 23 March 2016. See also Throsby 1997, 14-15, 2001, ch. 2; Hutter and Throsby 2008, 5.

67. Kalman 1974-75.

68. Jamie Bradburn, "Scenes from the Brunswick House," Torontoist, 30 November 2015, http:// torontoist.com/2015/11/scenes-from-the-brunswick-house.

69. Valverde 1998, 151.

70. Valverde 1998.

71. Cochrane 2005, 51-53; Deborah J. Godin's poetry is reprinted in Kalman 1974-75; Eric Mutrie, “Street Stories: Brunswick Avenue," Spacing: Toronto, 10 December 2010, http://spacing. ca/toronto/2010/12/10/street-stories-brunswick-avenue; Michelle Da Silva, "News of Brunswick House Closure Ignites Foggy Memories of Legendary Past," Think Free: The NOWToronto (blog), 27 November 2015 https://nowtoronto.com/news/think-free-blog/brunswick-house-closingignites-memories-of-legendary-past. Jamie Bradburn, "Scenes from the Brunswick House."

72. See, e.g., Celina Johnson, "The Past and the Future of the Brunswick House," blogTO, 24 April 2016, http://www.blogto.com/city/2016/04/the_past_and_the_future_of_the_brunswick_house.

73. Irene Stergiopoulos, "How I Learned to Stop Worrying and Love the Brunny," Toronto Standard, 9 January 2012, http://www.torontostandard.com/the-sprawl/how-i-learned-to-stop-worrying-andlove-the-brunny; Keenan 2013, 1.

74. Brissenden, "Brunswick on the Block."

75. Brissenden, "Brunswick on the Block"; Brissenden, "Brunswick House Has a Tenant."

76. "Brunswick House Denies Reports That Last Call Is Drawing Near," CBC News, 27 November 2015, http://www.cbc.ca/news/canada/toronto/brunswick-house-1.3339500. 
77. "Brunswick House Denies Reports That Last Call Is Drawing Near."

78. Brissenden, "Brunswick House Has a Tenant." City of Toronto, "Heritage Preservation, Heritage Property Detail."

79. Kalman 1974-75.

80. Burra Charter.

81. Burra Charter (emphasis in original). See also Throsby 1997, 14; Mason 2002, 10.

82. Canadian Register of Historic Places 2006, 10-11; Burra Charter, s. 1.2. See also Canada's Historic Places 2010.

83. Canadian Register of Historic Places 2006, 11.

84. As Throsby outlines, "[w]e can draw a distinction between what we might call 'hard' and 'soft' regulation. Hard regulation comprises enforceable directives requiring certain behaviour, implemented via legislation and involving penalties for non-compliance. Soft regulation comprises non-enforceable directives requiring certain behaviour, implemented by agreement and not involving penalties. Both types of regulation seek to change behaviour, the first by involuntary means, the second by encouraging voluntary compliance." Throsby 1997, 20.

85. OHA.

86. Gauthier 2013; UNESCO Convention.

87. See Quebec's Cultural Heritage Act; Newfoundland and Labrador, "Creative Newfoundland and Labrador: The Blueprint for Investment and Development in Culture," 2006, 34.

88. Deacon et al. 2004, 21.

89. Burra Charter, practice note, 7.

90. See, e.g., Mason 2002; de la Torre and Mason 2002. See also Higginbottom and Tonner 2010, 300.

91. Heritage Toronto and the Toronto Historical Association 2011, 4, 7.

92. Heritage Toronto and the Toronto Historical Association 2011, 4, 7. See also Convention on the Protection and Promotion of the Diversity of Cultural Expressions, 20 October 2005, 2440 UNTS 311; UNESCO Universal Declaration on Cultural Diversity, 2 November 2001, 31 C/Res. 15.

93. Logan and Molotch 1987, viii.

94. Hutchison 1988, 459. Note that use-value here, in the political economy literature, carries a different meaning than the way in which it is used in the cultural economics literature. In the latter, rather than the distinction between use-value and exchange-value, the distinction is drawn between use-value, or market value, and non-use-value, or non-market-value. Mason 2002, 13. Here, non-use values are similar to Logan and Molotch's description of use-value since non-usevalues are values "that are not traded in or captured by markets and are therefore difficult to express in terms of price. For instance, many of the qualities described as sociocultural values are also nonuse values." However, Logan and Molotch's use-value is not linked to market quantifiabilty or commodity exchange, whereas non-use values "can be classed as economic values because individuals would be willing to allocate resources (spend money) to acquire them and/ or protect them." Logan and Molotch 1987, viii; Mason 2002, 13. Non-use values in cultural heritage can then be further divided into existence value ("people value the existence of the heritage item even though they themselves may not consume its services directly"), option value ("people wish to preserve the option that they or others might consume the asset's services at some future time"), and bequest value ("people may wish to bequeath the asset to future generations"). Throsby 1997, 16, 2002, 103.

95. See also Throsby 2002, 104.

96. Graham, Ashworth, and Tunbridge 2000, 5. See also Tunbridge and Ashworth 1996.

97. De la Torre and Mason 2002; Mason 2002. For a recent example of a call for a more balanced approach in effectively acknowledging community and intangible heritage values within urban policy and decision making concerning heritage preservation, see Ryberg-Webster and Kinahan 2014, $131-32$.

98. Hae 2012, 6.

99. Chatterton and Hollands 2003, 238. But see Graham, Ashworth, and Tunbridge 2000, 24, who question whether the potentially subversive nature of heritage is subsequently neutralized upon 
attaining dominance, which leads to the question of whether the use-value of heritage, upon receiving equitable treatment, would then lose its potency and whether this would constitute a "capture" of Throsby's cultural capital in order serve a power legitimating purpose. Throsby 1997, 14-15, 2001, ch. 3.

100. Amy Terrill, "Making Music History Work for the Present," Huffington Post, 21 December 2015, http://www.huffingtonpost.ca/music-canada/preserving-music-history_b_8840870.html.

101. Graham, Ashworth, and Tunbridge 2000, 2; Higginbottom and Tonner 2010, 299-300.

102. Higginbottom and Tonner 2010, 299-300. See also Graham, Ashworth, and Tunbridge 2000, 4-5.

103. Higginbottom and Tonner 2010, 299-300.

104. Higginbottom and Tonner 2010, 299-300.

105. Throsby 2002, 107.

106. Burra Charter.

107. Throsby 2002, 109.

108. Throsby 2002, 109.

109. Throsby 2002, 107.

110. Chatterton and Hollands 2003, 240. Lehrer and Laidley 2008, 799-800. See also generally Hoyle 2000. Compare Foster, Kain, and Prentice 2011, 25.

111. See, e.g., AuthentiCity 2008; Foster, Kain and Prentice 2011; Lehrer, Keil, and Kipfer 2010, 82; Strategies for a Creative City Project, Imagine a Toronto; City of Toronto, Official Plan, 3.5.2; City of Toronto, Culture Plan for the Creative City.

\section{BIBLIOGRAPHY}

AuthentiCity. 2008. Creative City Planning Framework: A Supporting Document to the Agenda for Prosperity: Prospectus for a Great City. Toronto: City of Toronto.

Benson, Denise, ed. 2015. Then and Now: Toronto's Nightlife History. Toronto: Three O'Clock Press.

Berman, Stuart. 2015. "Foreward." In Then and Now: Toronto's Nightlife History, edited by Denise Benson, i-v. Toronto: Three O’Clock Press.

Canada's Historic Places. 2010. Standards and Guidelines for the Conservation of Historic Places in Canada: A Federal, Provincial and Territorial Collaboration. 2nd ed. Ottawa: Parks Canada.

Canadian Register of Historic Places. 2006. Writing Statements of Significance Ottawa: Parks Canada.

Chatterton, Paul, and Robert Hollands. 2003. Urban Nightscapes: Youth Cultures, Pleasure Spaces and Corporate Power. London: Routledge.

Cochrane, Glenn. 2005. Glenn Cochrane's Toronto: Tales of the City. Toronto: ECW Press.

de la Torre, Marta, and Randall Mason. 2002. "Introduction." In Assessing the Values of Cultural Heritage, edited by Marte de la Torre, 3-4. Los Angeles: Getty Conservation Institute.

Deacon, Harriet, et al. 2004. The Subtle Power of Intangible Heritage: Legal and Financial Instruments for Safeguarding Intangible Heritage. Cape Town, South Africa: HSRC Publishers.

Florida, Richard. 2002. The Rise of the Creative Class: And How It's Transforming Work, Leisure, Community and Everyday Life. New York: Basic Books.

Florida, Richard. 2005. Cities and the Creative Class. New York: Routledge. 
Foster, Robert J., Karen Kain, and Jim Prentice. 2011. Creative Capital Gains: An Action Plan for Toronto. Toronto: Toronto Arts Council.

Gauthier, Antoine. 2013. Intangible Cultural Heritage in Canada: Political Context, Safeguarding Initiatives, and International Cooperation. Quebec: Quebec Council for Intangible Cultural Heritage/ Conseil Québécois du Patrimoine Vivant. http://patrimoinevivant.qc.ca/wp-content/uploads/2013/ 04/Intangible-Heritage-in-Canada-ICHCAP-publishing.pdf.

Graham, Brian, G. J. Ashworth, and J. E. Tunbridge. 2000. A Geography of Heritage: Power, Culture and Economy. London: Arnold.

Grodach, Carl. 2013. "City Image and the Politics of Music Policy in the 'Live Music Capital of the World." In The Politics of Urban Cultural Policy: Global Perspectives, edited by Carl Grodach and Daniel Silver, 98-109. London: Routledge.

Grodach, Carl, and Daniel Silver. 2013. "Introduction: Urbanizing Cultural Policy.” In The Politics of Urban Cultural Policy: Global Perspectives, edited by Carl Grodach and Daniel Silver, 1-12. London: Routledge.

Hae, Laam. 2012. The Gentrification of Nightlife and the Right to the City: Regulating Spaces of Social Dancing in New York. New York: Routledge.

Handler, Richard. 2003. "Cultural Property and Culture Theory." Cultural Property and Culture Theory 3, no. 3: 353-65.

Heritage Toronto and the Toronto Historical Association. 2011. Heritage Voices: A Report Presented by Heritage Toronto and the Toronto Historical Association. Toronto: Heritage Toronto and the Toronto Historical Association.

Higginbottom, Gail, and Philip Tonner. 2010. “Archaeologies and Geographies of Value.” In Unquiet Pasts: Risk Society, Lived Cultural Heritage, Re-designing Reflexivity, edited by Stephanie Koerner and Ian Russell, 291. Burlington: Ashgate.

Hoyle, Brian. 2000. "Confrontation, Consultation, Cooperation? Community Groups and Urban Change in Canadian Port-City Waterfronts." Canadian Geographer 44, no. 3: 228-43.

Hutchison, Ray. 1988. “Book Review of Urban Fortunes.” American Journal of Sociology 94, no. 2: 459-61.

Hutter, Michael, and David Throsby. 2008. "Value and Valuation in Art and Culture: Introduction and Overview." In Beyond Price: Value in Culture, Economics, and the Arts, edited by Michael Hutter and David Throsby, 1-19. Cambridge: Cambridge University Press.

International Federation of the Phonographic Industry and Music Canada. 2015. The Mastering of a Music City: Key Elements, Effective Strategies and Why It's Worth Pursuing. Toronto: Music Canada.

Kalman, Rolf, ed. 1974-75. Toronto, We Love You. Toronto: Simon and Pierre Publishing.

Keenan, Edward. 2013. Some Great Idea: Good Neighbourhoods, Bad Politics and the Invention of Toronto. Toronto: Coach House Books.

Lehrer, Ute, Roger Keil, and Stefan Kipfer. 2010. "Reurbanization in Toronto: Condominium Boom and Social Housing Revitalization." disP: Planning Review 46, no. 180: 81-90.

Lehrer, Ute, and Jennifer Laidley. 2008. “Old Mega-Projects Newly Packaged? Waterfront Redevelopment in Toronto." International Journal of Urban and Regional Research 32, no. 4: 786-803. 
Lehrer, Ute, and Andrea Winkler. 2006. "Public or Private? The Pope Squat and Housing Struggles in Toronto.” Social Justice 33, no. 3: 142-57.

Logan, John R., and Harvey L. Molotch. 1987. Urban Fortunes: The Political Economy of Place Berkeley: University of California Press.

Mason, Randall. 2002. "Assessing Values in Conservation Planning: Methodological Issues and Choices." In Assessing the Values of Cultural Heritage, edited by Marte de la Torre, 5-30. Los Angeles: Getty Conservation Institute.

Music Canada. 2013. The Next Big Bang: A New Direction for Music in Canada. Toronto: Music Canada.

Oakley, Kate, and Justin O'Connor. 2015. "Culture and the City." In The Routledge Companion to the Cultural Industries, edited by Kate Oakley and Justin O'Connor, 201-11. London: Routledge.

Patterson, Matt, and Daniel Silver. 2015. "Turning the Post-Industrial City into the Cultural City: The Case of Toronto's Waterfront." In The Routledge Companion to the Cultural Industries, edited by Kate Oakley and Justin O'Connor, 268-80. London: Routledge.

Philippopoulos-Mihalopoulos, Andreas, ed. 2007. Law and the City. Abingdon: Routledge-Cavendish.

Rose, Nikolas, and Mariana Valverde. 1998. “Governed by Law?” Social and Legal Studies 7, no. 4: 541-51.

Ryberg-Webster, Stephanie, and Kelly L. Kinahan. 2014. "Historic Preservation and Urban Revitalization in the Twenty-First Century." Journal of Planning Literature 29, no. 2: 119-39.

Throsby, David. 1997. "Seven Questions in the Economics of Cultural Heritage." In Economic Perspectives on Cultural Heritage, edited by Michael Hutter and Ilde Rizzo, 13-30. London: Macmillan Press.

Throsby, David. 2001. Economics and Culture. Cambridge: Cambridge University Press.

Throsby, David. 2002. "Cultural Capital and Sustainability Concepts in the Economics of Cultural Heritage." In Assessing the Values of Cultural Heritage, edited by Marta de la Torre, 101-17. Los Angeles: Getty Conservation Institute.

Throsby, David. 2010. The Economics of Cultural Policy. Cambridge: Cambridge University Press.

Titan Music Group. 2012. Accelerating Toronto's Music Industry Growth: Leveraging Best Practices from Austin, Texas. Toronto: Music Canada.

Tunbridge, J. E., and G. J. Ashworth. 1996. Dissonant Heritage: The Management of the Past as a Resource in Conflict. Chichester: John Wiley and Sons.

Valverde, Mariana. 1998. Diseases of the Will: Alcohol and the Dilemmas of Freedom. Cambridge: Cambridge University Press.

Winthrop, Robert. 2002. "Defining a Right to Culture, and Some Alternatives." Cultural Dynamics 14, no. 2: 161-83.

Zukin, Sharon. 2010. Naked City: The Death and Life of Authentic Urban Places. Oxford: Oxford University Press. 